\title{
当院で経験した傍卵巣囊腫症例の検討 \\ Clinical features of paraovarian cysts
}

大分東部病院 産婦人科

岡田さおり、古賀 修、吉武朋子

\section{目的}

傍卵巣囊腫は付属器腫瘤の約 $10 \%$ の発生頻度で、 開腹手術時にしばしば認められる。臨床的には子 宮付属器領域の卵巣とは独立した囊胞を傍卵巣囊 腫あるいは傍卵管囊腫と呼んでおり、明確に区分 されていないようである。術前の超音波検査によ る卵巣囊腫との鑑別は困難で、卵巣囊腫の診断で 手術となった場合が多い1)。また良性の貯留囊胞 であることから、傍卵巣囊腫の病理診断について の本邦での報告は少ない。今回、当院で経験した 傍卵巣囊腫10例について術前検査所見、手術所見 および病理所見について報告し、傍卵巣囊腫に対 する腹腔鏡手術の有用性について検討することを 目的とした。

\section{対象および結果}

腹腔鏡手術にて傍卵巣囊腫と確定診断された 10 例を対象とした（表 1 ）。

患者は19歳から75歳 (平均：34.9歳)、2 例は閉 経後、8 例が生殖年齢婦人で挙児希望例であった。 囊胞の大きさは $5 \mathrm{~cm}$ から $14 \mathrm{~cm}$ 、右側 4 例、左側 6 例であった。主訴は下腹痛が 7 例、他疾患の画像

\begin{tabular}{|c|c|c|c|c|c|c|c|c|}
\hline \multirow{2}{*}{ 症例 } & \multirow{2}{*}{ 年鈴 } & \multirow{2}{*}{ 左右 } & \multirow{2}{*}{ 主訴 } & \multirow{2}{*}{$\begin{array}{c}\text { 需胞径 } \\
(\mathrm{cm})\end{array}$} & \multicolumn{3}{|c|}{ 両側の正常卵巢の描出 } & \multirow{2}{*}{ 術前診断 } \\
\hline & & & & & 経捀超音波 & CT & MRI & \\
\hline 1 & 19 & 右 & 下腹痛 & 5 & 0 & 0 & - & 傍卵宩囊㯵 \\
\hline 2 & 19 & 左 & 下腹痛 & 6 & 0 & $x$ & - & 傍卵巣潩腫 \\
\hline $3 *$ & 23 & 右 & 下腹痛 & 5 & 0 & - & 0 & 傍卵巣筤睡 \\
\hline 4 & 24 & 左 & 下腹痛 & 6 & $x$ & $x$ & - & 卵㢼表畽 \\
\hline 5 & 26 & 左 & 下腹痛 & 5 & 0 & - & 0 & 傍卵果繋腫 \\
\hline 6 & 27 & 右 & 好娠 & 5 & o & - & 0 & 傍卵果茜畽 \\
\hline $7 *$ & 33 & 左 & 下腹痛 & 8 & $x$ & 0 & - & 傍卵䉾表腫捻転 \\
\hline 8 & 42 & 右 & 交通事故 & 5 & $x$ & - & $x$ & 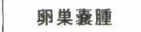 \\
\hline 9 & 61 & 左 & 下腹痛 & 14 & $x$ & $x$ & $x$ & 莭巣表腫 \\
\hline 10 & 75 & 左 & 胆石症 & 6 & $x$ & $x$ & - & 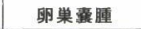 \\
\hline
\end{tabular}

* 傍卵苹囊腫に伴う卵管捻転
診断で偶然指摘されたものが 2 例、妊娠が 1 例で あった。また傍卵巣囊腫に伴う卵管捻転が 2 例に 認められた。

術前検查として、経腔超音波揖よびCTまたは MRIを施行した。震胞の経腔超音波の所見は全例 で囊胞壁が薄く単房性で、anechoicであった。壌 胞の傍らに複数の小さな卵胞を有する正常卵巣を 認め、また対側の卵巣も同定できたものは傍卵巣 襄腫と診断した（写真 1 )。経胵超音波にてこの 所見を得られたものは 5 例であった。CTにて両側 卵巣を同定することにより傍卵巣囊腫と診断でき たものは、6 例中 2 例であった。捻転を生じた 1 例は経㓐超音波にて診断することができなかった が、CTにて震胞性腫瘤壁に出血壊死と思われる所 見が認められたことや、肥厚した間膜と思われる 所見を伴っていたこと、および同側の卵巣が描出 されたことにより傍卵巣囊腫に伴う卵管捻転と診 断することができた（写真 2 )。MRIが施行され

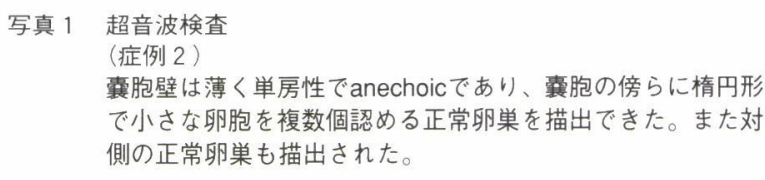

囊胞壁は薄く単房性でanechoicであり、囊胞の傍らに情円形 で小さな卵胞を複数個認める正常卵巣を描出できた。また対 側の正常卵巣も描出された。

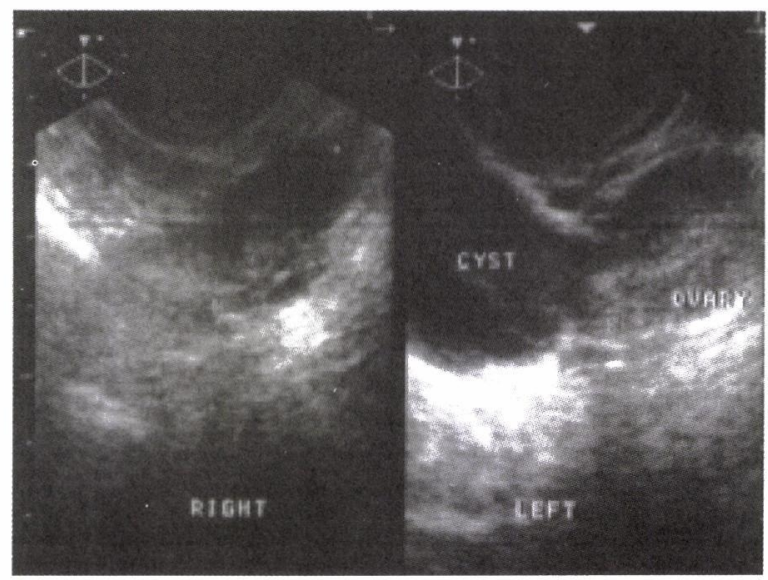


写真 2 C T

(症例 7 傍卵巣囊腫に伴う卵管捻転)

単純C Tにて、囊胞性腫瘤壁は偏心性に厚く高吸収を呈して おり、出血壊死が疑われた。壁の左背唄部分はこぶ状の軟部 組織を認め、形態から捻転した間膜に相当するものと思われ た (矢印)。

造影Ｃ下にて賈胞性腫瘤の譬にほとんど造影効果がなく、 らに正常な造影効果を有する左卵巣（矢印）が同定された。

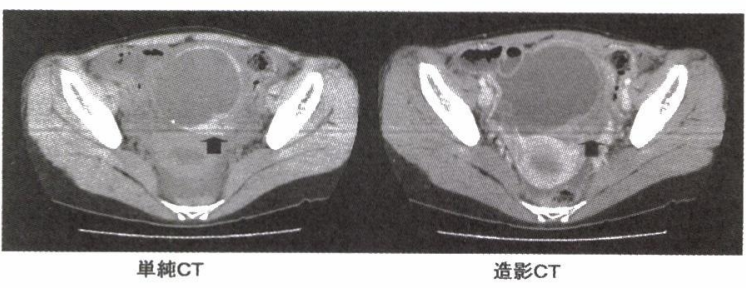

た 5 例では、腫瘤はすべてT1強調画像（T1WI） で低信号、T2強調画像（T2WI）で均一な高信号 の単房性囊胞として描出された。同側に複数の卵 胞を有した卵巣が変形なく認められ、傍卵巣囊腫 と診断することができたものは 3 例であった（写 真 3 )。以上より、術前画像診断で傍卵巣囊腫と 診断することができたものは 6 例で、卵巣囊腫の 診断で手術に至ったものは 4 例であった（表 1 ）。

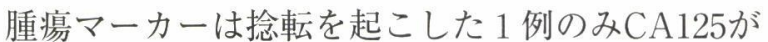
63U/mlと高值を示していたが、他の症例では正常 範囲であった。

\section{写真 $3 \mathrm{MRI}$}

(症例 3)

MRIでは、T1W | で低信号、T2W | で均一な高信号の単房性 霋胞で、同側に複数の卵胞を有した卵巣が变形なく認められ た。

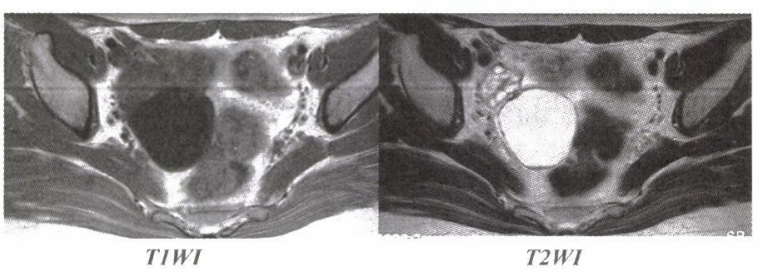

腹腔鏡手術は、臍縁に $5 \mathrm{~mm}$ 、左右の下腹部に 患側は $12 \mathrm{~mm}$ 、対側に $5 \mathrm{~mm}$ のトロッカーを挿入 し、気腹法で行った。トロッカーは、エンドパス トロッカーシステム（ジョンソン・エンド・ジョ ンソン株式会社)、またはセパレータートロッカ ーシステム（株式会社メディカルリーダーズ）を 使用した。手術術式は、閉経後の 2 例および傍卵 宩囊腫に伴う卵管捻転の 2 例は、ハーモニックス カルペル（オリンパス）を用いて傍卵巣囊腫とと もに卵管切除術を施行した (写真 4)。他の 6 例 については体腔内法（3 例）および体腔外法（3 例）により傍卵巣囊腫のみ摘出した。体腔内法で は卵管間膜を切開し、囊腫を核出した。3 例とも 囊腫を破綻することなく摘出可能であり、エンド
写真 4 腹腔鏡所見

（症例 3 傍卵巣囊腫に伴う卵管捻転 卵管切除術） 右卵管膨大部直下に超鶏卵大の傍卵巣囊腫を認め、卵管が傍 卵巣囊腫とともに 2 回転の捻転を起こしていた。捻転を解除 したが、すでに卵管および傍卵巣囊腫は赤暗色変化をきたし ていたため、傍卵巣囊腫も含めて卵管切除を施行した。

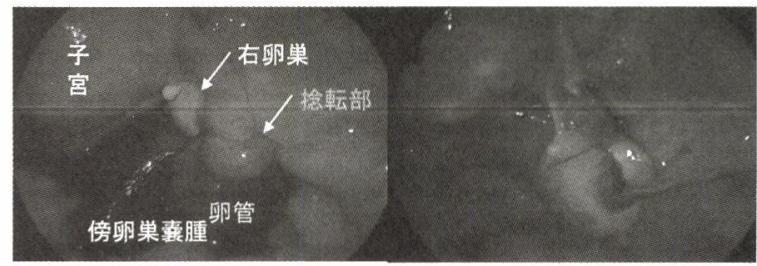

写真 5 腹腔鏡所見

(症例 5 囊腫摘出術 体腔内法)

衂管間膜を切開し、囊腫を破綻することなく核出した。エン ドキャッチに収容して内容液を吸引後、体腔外へ取り出した。 卵管間膜の切開創は、縫合閉鎖した。
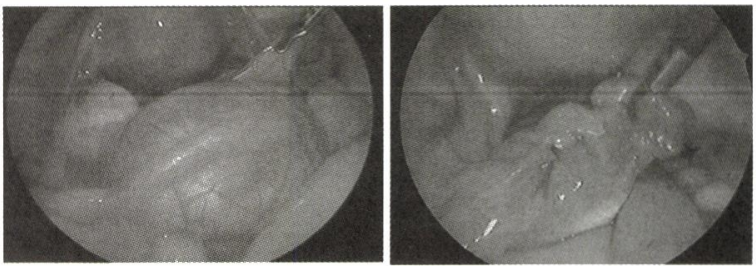

キャッチ（タイコヘルスケアジャパン株式会社） に収容して内容液を吸引後、体腔外へ取り出した。 卵管間膜の切開創は、縫合またはラパロクリップ （タイコヘルスケアジャパン株式会社）で閉鎖し た（写真 5 ）。体腔外法では、囊腫をサンドバル ーンカテーテル（株式会社八光）で穿刺吸引後、 体腔外へ取り出し、囊胞壁を核出して切開創を縫 合し、体腔内へ戻した。

内容液は症例 6 のみ粘液性で、他は漿液性透明 であった。捻転を起こした 2 例は囊胞内出血を起 こしていた。病理診断は全例良性で、組織型は、 Mullerian typeが 8 例、Mesothelial type（写真 6 ）が2例であった（表 2 ）。症例6はMullerian typeの囊胞壁の一部に腫瘍性の変化があり、病理 組織はadenofibromaであった（写真 7$) 。$
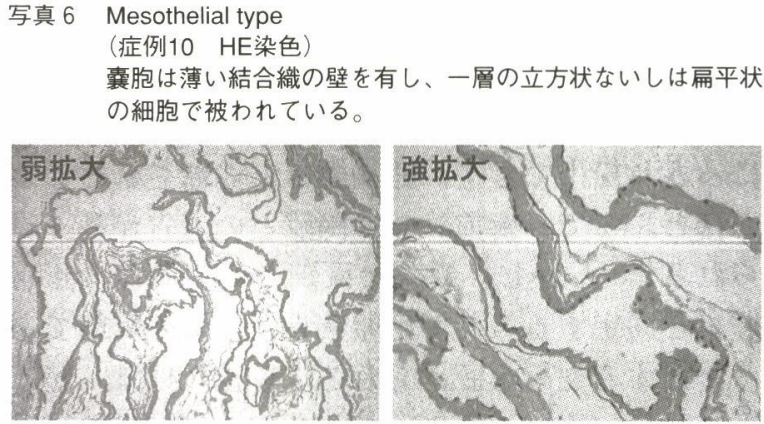
表 2 術式および病理組織診断

\begin{tabular}{|c|c|c|c|}
\hline 症例 & 術式 & 内容液 & 病理 \\
\hline 1 & 囊腫摘出術(体腔内法) & 䟿液性 & Mullerian \\
\hline 2 & 異腫摘出術(体腔外法) & 慗液性 & Mulle rian \\
\hline 3* & 卵管切除術 (体垁内法) & 出血 & Mulle rian \\
\hline 4 & 襄腫摘出術(体㬶外法) & 醬液性 & Mullerian \\
\hline 5 & 䡛腫摘出術(体貯内法) & 鏊液性 & Mes othe lial \\
\hline 6 & 表腫摘出術(体腔内法) & 粘液性 & Mullerian (adenofibroma) \\
\hline $7 *$ & 卵管切除術(体腔内法) & 出血 & Mullerian \\
\hline 8 & 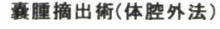 & 跢液性 & Mullerian \\
\hline 9 & 卵管切除術(体腔内法) & 熬液性 & Mulle rian \\
\hline 10 & 卵管切除術 (体腔内法) & 牃液性 & Mesothe lial \\
\hline
\end{tabular}

* 傍卵巣蓑腫に伴う卵管捻転

写真 7 Mullerian type (adenofibroma)

(症例 6 HE染色)

Mullerian typeの囊胞壁囊胞は豊富な結合織の厚い壁を有し、 内面は一層の円柱状の細胞で被われている。円柱状の細胞の 表面には絾毛が認められる。

壁の一部に腫瘍性の変化が認められた。腫瘍は乳頭状で、表 面を円柱上皮が被い、その下層では線維芽細胞と膠原線維が 增生しているadenofibromaであった。

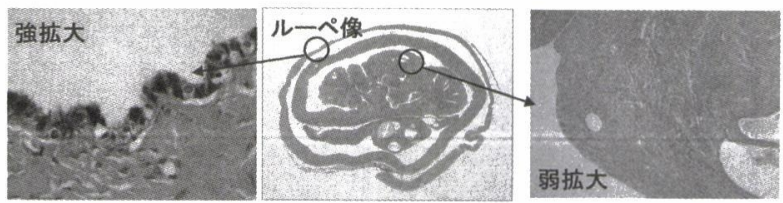

考察

胎生期の生殖管は、中腎管 (Wolff管) と中腎傍 管（Muller管）の2つが存在している。女児では Muller管が分化し子宮および卵管を形成する。 Wolff管は通常退行変性していくが、このときの退 行変性が不十分で遺残してしまうとさまざまな名 称で呼ばれる㓔痕器官となる。具体的にはWolff管 が子宮外側壁に沿って子宮広間膜の間に管状構造 物として遺残すればGartner管、囊腫化すれば Gartner管囊腫、Wolff管の頭方端が残存すれば胞 状垂、卵巣と卵管の間に残存する少数の盲状細管 を卵巣上体，または卵巣傍体と呼称する。また Muller管の卵管采側の痕跡囊胞はMorgagni小胞と 呼称する。傍卵巣 (卵管) 囊腫はおそらくこれら の痕跡器官を総称したもので、狭義には卵巣上体 から発生する貯留囊胞である ${ }^{2)}$ 。

超音波検査では、術者の技量や装置の解像度に かなり影響されるが、卵巣と傍卵巣囊腫の境界を はっきり描出できず、卵巣囊腫と診断されること がほとんどで、術前診断は困難との報告が多く見 られる ${ }^{3)}$ 。しかし、囊胞と区別される同側の正常 卵巣を同定することで傍卵巣襄腫と診断可能であ ったとする文献も認められる。Kimら ${ }^{4)}$ は、20歳 から67歳（平均：36歳）の42症例、傍卵巣囊腫46 例の超音波診断の特徵を検討している。全例で囊 胞壁が薄く単房性で、46例中43例がanechoic と述 べている。また $76 \%$ に同側の正常卵巣を同定する ことで傍卵巣囊腫を診断できたとしている。

MRIでは、T1WIで低信号、T2WIで均一な高信 号を呈する単房性囊胞で、超音波検査と同様に同 側の正常卵巣を同定することで傍卵巣囊腫と診断 できる。また、円勒帯を同定してその付近に存在 すること、同側に複数の卵胞を有した卵巣を変形 なく認めることなどを特徴として挙げている5)。 逆に、囊胞に接した半月状に残存した卵巣組織を 認める場合（beak sign）や拡張した血管を認める 場合は卵巣腫瘍の可能性が高い5)。

当院の症例では、経腨超音波およびCTまたは MRIの組み合わせで、上記のような所見から10例 中 6 例は術前診断することが可能であった。閉経 後の 2 例では、萎縮した卵巣を同定することがで きず、術前診断は困難であった。

傍卵巣囊腫は発生母地として中腎管 (Wolff管) 由来、中腎傍管（Muller管）由来、腹膜中皮由来 の 3 種類がある ${ }^{6)}$ 。

病理組織学的には、卵管 (Muller管) 由来の上 皮（Mullerian type）は繊毛を有す分泌細胞を含 む一層の円柱上皮により覆われ、薄い筋層に囲ま れている。腹膜中皮由来 (Mesothelial type) の 囊胞は扁平な上皮である。Wolff管由来の囊胞は丈 の低い立方形の上皮で比較的厚い筋層に覆われて

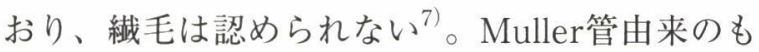
のを傍卵管䡛腫と呼び、腹膜中皮およびWolff管由 来のものを傍卵巣囊腫と呼んでいる報告も認めら れる ${ }^{3)}$ 。Samahaら ${ }^{6)}$ は、79例の傍卵巣囊腫につい て $76 \%$ がMuller管由来、 $24 \%$ が腹膜中皮由来、 Wolff管由来は認められなかったと報告している。 Genadry ( $^{8)}$ は132例の傍卵巣襄腫のうち、68\%が 腹膜中皮由来、30\%がMuller管由来、 $2 \%$ がWolff 管由来であったとしている。当院の症例では、 Muller管由来が 8 例、腹膜中皮由来が 2 例であり、 Wolff管由来のものは認められなかった。

Genadry $^{8)}$ はまた、傍卵巣囊腫のうちで 8 例 の腫瘍性病変を報告している。良性腫瘍では cystadenofibroma、悪性腫瘍ではpapillary serous cystadenocarcinomaをそれぞれ 4 例に認め、すべ てMuller管由来であった。Steinら ${ }^{9)}$ は、168例の うち3例 $(2 \%)$ で悪性所見が見られたと報告して いる。危険因子として、生殖可能年齢であること、 襄胞径が $5 \mathrm{~cm}$ 以上で、経㓐超音波にて襄胞内腔に 乳頭状あるいは充害性部分を有することを挙げて いる。当院の症例では、 10 例中 1 例に良性の腫瘍 
性病変を認めたが、画像診断では全例充実性部分 は認められなかった。

$\mathrm{Pepe}^{10)}$ らによると、傍卵巣囊腫はすべての年 齢に起こりうるが好発年齢は20から50歳、大きさ は 5 から $10 \mathrm{~cm}$ が多く、10cmを超えるものは約 $20 \%$ と報告されている。また、小さいものでは無 症状のことが多いが $5 \mathrm{~cm}$ 以上のものでは下腹部 痛、腹部膨満感などの症状を示し、茎捻転による 急性腹症の症状を引き起こすこともある ${ }^{11)}$ 。さら に傍卵巣囊腫により卵管が引き伸ばされている場 合があり不妊の原因にもなりうる ${ }^{12)}$ 。

傍卵巣囊腫は生殖年齢婦人に多く、痛みが続く 場合はもとより、卵管捻転を起こせば卵管切除と なることから、妊孕性を温存することを考慮すれ ば、無症状であっても経過観察せず手術を施行す るべきであると考える。また、傍卵巣囊腫の中に 悪性のものが存在しうるという認識は必要ではあ るが、ほとんどが良性であるということ、また多 くの症例で囊腫の核出は容易であり、内容液は槳 液性で内容液吸引後の襄腫壁は薄く、 $12 \mathrm{~m} \mathrm{~m}$ トロ ッカーの傷から取り出せることから腹腔鏡手術の よい適応となると考えられる。

本論文の要旨は第 47 回日本産科婦人科内視鏡学 会において発表した。

\section{文献}

1）山道力子、石原剛、関正明：腹腔鏡下に治療した卵管 捻転の1例、三豊総合雑誌、26:137, 2005.

2) 小橋優子他：術前診断が困難であった傍卵巣（傍卵 管）囊腫茎捻転の 1 例、日本小览放射線学会雑誌、 $22: 65,2006$.

3) Barloon TJ et al. : Paraovarian and paratubal cysts: preoperative diagnosis using transabdominal and transvaginal sonography. J Clin Ultrasound 24: 117, 1996.

4) Kim JS et al. : Sonographic diagnosis of paraovarian cysts: value of detecting a separate ipsilateral ovary. AJR Am J Roentgenol 164: 1441, 1995.

5 ) Kishimoto $\mathrm{K}$ et al. : Paraovarian cyst: MR imaging features. Abdom Imaging 27: 685, 2002.

6 ）武谷雄二編：卵管の良性腫瘍、類腫瘍病変、新女性医 学大系39産婦人科の良性腫瑒、27、中山書店、2001.

7 ) Samaha M, Woodruff JD : Paratubal cysts: frequency, histogenesis, and associated clinical features. Obstet Gynecol 65: 691, 1985.

8 ) Genadry R, Parmley T, Woodruff JD : The origin and clinical behavior of the paraovarian tumor. Am J Obstet Gynecol 129; 873, 1977.
9 ) Stein AL et al. : Relative frequency of malignant paraovarian tumors: Sould paraovarian tumors be aspirated ? Obstet Gynecol 75: 1029, 1990.

10) Pepe F. et al. : Paraovarian tumors. Eur J Gynaecol Oncol $3: 159,1986$.

11) Varras $\mathrm{M}$ et al. : A voluminous twisted paraovarian cyst in a 74-year-old patient: case report and review of the literature. Clin Exp Obstet Gynecol $4: 253,2003$.

12）佐藤（田中）佐和子他：当院における傍卵巣襄腫症例 の検討、日産婦内視鏡学会誌、20: 187, 2004. 